.Research Article

\title{
Youth Unemployment: The Cause of Ethnic Conflict and Criminal Activities in Takum Local Government Area of Taraba State Nigeria
}

\author{
Shimfe, Harry Grace \\ Department Of Sociology \\ Federal University, Wukari \\ 200 Katsina-Ala Road, P.M.B 1020 Wukari, Nigeria \\ e@Gmail.Com \\ 08034477313 \\ And \\ John Wajim \\ Department Of Sociology \\ Federal University, Wukari \\ 200 Katsina-Ala Road, P.M.B 1020 Wukari, Nigeria \\ Wajim@Fuwukari.Edu.Ng \\ 08036363346
}

\begin{abstract}
:
This research work examined youth unemployment: the cause of ethnic conflict and criminal activities in takum lga of taraba state, nigeria. unemployment to a large extent remains nigeria's socio-economic and political problem. historically, unemployment situation in the country was heightened by the introduction of structural adjustment programme (sap). cross-sectional research design was used for this; both primary and secondary sources of data collection were employed for the success of the research work. simple percentages were applied on a cross-sectional data of 120 sampled unemployed youths randomly selected from takum local government area in 2016. the study revealed that lack of employment opportunities stimulate young people to engage in ethnic conflict and criminal activities such as theft, arm robbery, kidnapping etc., in order to survive and earn material success. the study recommends that government should create more jobs opportunities and industries so that unemployed youths can be absorbed in order to meet their immediate needs, as this will drastically curtail ethnic conflict and criminal activities by the unemployed youth in the study area.
\end{abstract}

Keywords: Youth Unemployment, Ethnic Conflict, Crime, Takum, Taraba State.

\section{Introduction:}

The Nigeria economic since the attainment of political independence in 1960 has undergone fundamental structural changes resulting to structural shift which have however not resulted in any significant sustainable economic growth and development to ensure adequate employment opportunity for her teaming youths. Recently, available data show that the Nigeria economy grew relatively in the greater parts of the 1970s whose extreme profits resulted to wasteful expenditures in the public sector leading to dislocation of the employment factors and also dislocation of the resulted in the revenue bases for policy planning. This among many others crises resulted in the introduction of the structural adjustment programmed (SAP) IN 1986 and the recent economic reforms. The core objective of the economic structural reform is a total restructuring of the Nigeria economic in the face of population explosion (Douglaston et al., 2006).

However, these economic and financial structural reforms put in place did not yield significant 
results, hence in recent past; there has been an alarming increase in the rate of youth unemployment and its attendant social and economic problems. Unemployment is one of the developmental problems that face every developing economy (Patterson et al., al 2006). And Nigeria as a multi-lingual macrocosm is not exempted; its impact has been felt more by the youths.Thermmion developing countries like Nigeria, governments and policy makers are increasingly finding it difficult to grapple successful with unemployment. This high rate of unemployment can be blamed on the lack of adequate provision for job creation in the development plans, the ever expanding educational growth and the desperate desire on the part of youths to acquire university education irrespective of course and course contents. As a result, a number of skills acquired from the university appear dysfunctional and irrelevant (Okafor, 2011). Unemployment is one of the social problems that retard human development and breed poverty, which in turn lead to low level of consumption and income. The problem of unemployment in Nigeria has been increasing everyday alongside with crime wave. The worrisome aspect of the phenomenon is that it is not limited to people with poor educational background alone, it is equally well pronounced among university graduates.Unemployment to a large extent remains Nigeria's socio-economic and political problem. Historically, unemployment situation in the country was heightened by introduction of structural adjustment programme (SAP) in (1986). Over the years government has made effort to curtail this problem such as the institutionalization of National directorate of employment (NDE) among other programmes. However, increasing trend in the incident of unemployment seems to continue unabated in spite of such efforts. Consequently, series of social problems have emanated out of the above scenario. More worrisome is the problem of crime and unemployment and the general insecurity in the society. Basically, this study seeks to investigate youth unemployment as the cause of ethnic conflict and criminal activities in Takum LGA of Taraba State, Nigeria.

\section{Conceptual Clarification \\ Crime:}

Elizabeth, (2003) asserted that crime is an act harmful not only to some individual or individuals but also to a community, society or the state ("a public wrong"). Such acts are forbidden and punishable by law. In ordinary language, the term crime denotes an unlawful act punishable by a state. The term "crime" does not, in modern criminal law, have any simple and universally accepted definition, through statutory definitions have been provided for certain purposes.

that acts such as murder, rape and theft are to be prohibited exist worldwide (Easton 2010). What precisely is a criminal offence is defined by criminal law of each country. While many have a catalogue of crimes called the criminal code, in some common law countries no such comprehensive statute exists.

The state government) has the power to severely restrict one's liberty for committing a crime. In modern societies, there are procedures to which investigations and trials must adhere. If found guilty, an offender may be sentenced to a form of reparation such as a community sentence, or, depending on the nature of their offence, to undergo imprisonment, life imprisonment or in some jurisdiction,

Usually, to nnbe classified as a crime, the "acts of doing something criminal" (actusreus) must - with certain exception - be accompanied by the "intention to do something criminal" (mensrea) (Elizabet 2003).

While every crime violates the law, not every violation of the law counts as a crime. Breaches of private law (torts and breaches of contract) are not automatically punished by the state, but can be enforced through civil procedure.

Crime is defined as any act that violates the law. Hence, it is defined relative to laws, and varies from society to society or omission, from state to state, from time to time, and from strict enforcement to none.

To Emile Durkhien, crime is a category which can be defined only by reference to the specific social norms and values of the society in which it occurs. Durkheim does not regard some action as crime absolutely; he recognizes that given the whole of human social experience, crime should be that which contradicts the collective sentiment of the social group.

Crime is categorized as follows:

- Moral crime (victimless crime) - violation of law in which there are no readily apparent victim such as prostitution, gambling, vagrancy, purchasing illegal drugs like cannabis or marijuana. 
- Property crimes - common crimes committed in industrial societies, including robbery burglary and larceny.

- Violent crimes - involve threat of violence; include murder, manslaughter, infanticide, assault, sexual assault, abduction and robbery.

\section{Youth:}

United Nations situates "Youth Cycle" between the end of childhood and entry into the world of work (adulthood). It is also an "age-related process" which varies from society. No matter the controversy about the takeoff point of the youth cycle, it is not arguable that the terminal point of youth cycle marked the threshold to adulthood.

\section{Unemployment:}

It is a state in which a person is without a job (work), ready to work and is looking for work. According to ILO (International Labor Organization) unemployed workers are those who are currently not working but are willing and able to work for, currently available to work and are actively searching for work. The operational definition of unemployment as it concern this study means people who have lived without jobs or employment in which case their living standard become burden to themselves and other members of the society. The International Labor Organization (ILO) defines the unemployed as numbers of the economically active population who are without work but avail themselves for work opportunity. Including people who have lost their jobs and those have voluntarily left work. According to Shankaru, (2006) unemployment is a condition in which an individual is not in a state of remunerative occupation despite the desire to do so. Chinqunta, (2002) defines unemployment as a visible idleness where youth congregate at bars and drinking places to converse or smoke Marijuana for substantial part of the day. Gardens (2001) on the other hand views unemployment as individuals who are without job, who are available to start work within two weeks and have attempt to work for a job within a previous month. Unemployment occurs when people are without work and actively seeking work (ILO, 2007). The unemployment rate is a measure of the prevalent of unemployment and is calculated as a percentage by dividing the number of unemployed individuals by all individuals currently in the labor force.

\section{Ethnic Conflict:}

An ethnic conflict or ethnic war is an armed conflict between ethnic groups. It contrasts with civil war on one hand (where a single nation or ethnic group fighting among itself) and regularly warfare on the other, (where two or more sovereign state are in conflict) (Wikipedia, the free encyclopedia).

\section{Ethnicity:}

Is a category of people, who identify with each other base on common ancestral, social, cultural or national experience. Unlike most other social groups, ethnicity is primarily an inherited status. Membership of an ethnic group tends to be defined by a shared cultural heritage, ancestry, origin myth, history, homeland, language and/or dialect, symbolic systems such as religion, mythology and ritual, cuisine, dressing style, art, and physical appearance (Oxford Dictionaries, 2013).

\section{Theoretical Consideration:}

Over the years so many theories were postulated and developed by different erudite scholars in the discipline of sociology but Robert King Merton's strain theory was considered for this research work for proper justification.

\section{Robert King Merton's Strain Theory:}

Robert K. Merton is an American sociologist born on $4^{\text {th }}$ July, 1910 and died on the $23^{\text {rd }}$ February, 2003. His strain theory is an adaptation of Durkheim's anomie theory that emerges from the functionalist perspective. Merton 1968 builds on Durkheim's ideas by arguing that crime results from the culture and structure of the society itself. $\mathrm{He}$ begins from the standard functional position of value consensus that all members of the society share the same values. However, since numbers of the society are placed in different positions in the social structure (for example, they differ in terms of class position). They do not have the same opportunity in realizing the share value. This situation can generate deviance (Haralambos, 2004). The strain theory states that social structures may pressure citizens to commit crimes. Strain may be structural, which refers to the processes at the societal level that filter down and affect how the individual perceives his or her needs.Merton, (1938) posited that two social structures are involved in the strain theory; first is the culturally 
assigned goals and aspiration which are things that all individuals should want and expect out of life including both material and non material things. The second defined the acceptable means for achieving the goals and aspiration set by the society. For example, obeying laws and societal norms, seeking education and working hard. Merton argued that, there might not be a problem if everybody has equal access to these institutionalized means for achieving the sought after goals. However, if goals are not achieved through legitimate means, illegitimate means might be used to achieve the same goals. According to Merton, there is often a gap or what he called "anomie" (which is a common occurrence when people's expectation about reward and gratification are not closely matched) between goals and means. Too much emphasis is place on the goals and not enough emphasis is placed on ways of achieving these legitimate goals. This leads individuals to seek out the goals by whatever means, through this process, crime is showcased. Simply put over emphasis on material success leads to crime. The aforesaid theory is strongly linked to the research work because it vividly explains why some individuals engage into ways that are not acceptable by the society in order to carter for themselves.

\section{Major Strengths/Limitations Of The Theory:}

The theory gives an insight to understanding the functional integrations of different parts of society to see where strains are likely to emerge. Example, strains are likely to emerge when school teaches people goals and expectations and the economy does not give them opportunity to fulfill them legally.The major limitation of this theory is its assumption that there is valued consensus and people only deviate as a result of structural strain. It has been criticized for being deterministic because it fails to explain why some people who experience the effect of anomie do not become criminals.For the purpose of this research, the strain theory by Robert Merton is more appropriate as the theoretical underpinning of the study. This is because the theory best offers the connection between the following variables (unemployment and ethnic conflict/crime). Firstly, the Nigerian social structure could be blamed for its inability to put in place necessary structures such as industries that would generate employment for the teaming graduates. This further worsened when these graduates are faced with difficulties of getting employed in the few exiting government establishments. Thus, face with necessity to acquire the material goods that are much emphasized in Nigeria, these youths (graduates) unavoidably becomes criminals in order to acquire these cultural goals.Following the major tenets of Merton's theory, individuals (youths) who experience strain in seeking culturally assigned goals through legitimate means (employment) could respond to the end -means dilemma through innovation (criminal activities). Therefore, the link between unemployment and ethnic conflicts/crime could be explained as the outcome of the structural defects in Nigerian society.Unemployment as a social problem is a serious threat to Nigeria as a nation state due to the facts that over the years a lot of criminal activities and ethnic conflict which are great impediments to meaningful development in our dear society are taking place as the result of youth joblessness, based on the popular adage that says, "an idle mind is the devil's workshop". And most unemployed youth who are looking for their sources of livelihood have no choice than to embark on any available employment opportunity even though such opportunity may cause devastation in the society.

\section{Unemployment And The Incidence Of Crime Among Youths In Nigeria:}

The scariest undertone of Nigeria's socio-economic under achievement, by far, is the steady rise in youth crime, nurtured in a climate of increasing national income and simultaneous failure of employment, generation and poverty alleviation programmes. Armed insurgencies ravaging the oilrich and volatile Niger region are now competing for space in international headlines with proliferation of Islamic terrorist offshoots. The season of discontent has a special ramifications for a nation with unemployed millions, and the net effect has been tragic precipitation of violent crimes; assault, burglary, extortion and kidnapping. Further, decades of social and political turmoil helped turn this strategically located nation into an established junction for international drug smuggler. Other highlights of Nigeria's prolific crime syndicates are economic fraud, usually in the form of innovative internet schemes, money laundering and racketeering.It is common observation for many countries that unemployment rate and crime rates are positively related. The 
situation in Nigeria is equally same. Statistics has same. A remarkable increase in youths' unemployment and consequently involvement of such youths in arm robbery.According to the Bureau of Statistics Annual Report, (2007) there were 47, 991 Bachelor degree youths in 2001. This increased to 58,305 in 2002 and 70,361 in 2003. The statistic revealed that youth's unemployment rate $35.5 \%$ while in 2004 it rose to $41.1 \%, 48.8 \%$ in 2005 and $49.9 \%$ in 2006. The above statistics justifies the observation by Ityaryar, (2000) who stated that, youth unemployment is no longer cyclical and temporal but structurally and apparently permanent. Ibebuke, (2008) asserted that unemployment is one of the major causes of incessant armed robbery in Nigeria, he succinctly opined that;"A graduate who is unable to get a job and who out of frustration is psychologically bereft of any concept or idea of survival, such a person will definitely developed a negative attitude towards the social structure and will attribute his failure to the society's failure and the only way to manifest his integration is by constituting a terror to the well of society"

\section{The Nigerian Social Structure And Crime:}

The involvement of Nigerian youth into arm robbery and many other crimes like theft, advanced fee fraud (149), thuggery etc., is either the product or the nature of the organizational structure of the Nigerian society which is based on the capitalist mode of production shapes by the other aspect of social life, the political system, the legal system, the ideological system (Ake, 1981).Consequently, this increase the wretchedness of the under privileged masses. Children of the majority are confronted with challenging experiences of inability to acquired good quality education and employment. Consequently, they take to crime in order to survive because of their social class (Zumve, 2005).Pittz, (2001) maintained that unemployment, another prominent feature of the Nigerian social structure has a causal relationship with youth criminality. The stratified nature of Nigerian society and its dominant social class features nepotism and ethnicity; and its plays a very important role on the issue of unemployment. First of all it is only the youth who through their social background with means and connection, good education are meant to get employment. The underprivileged who through hardship acquired education are later faced with the problem of unemployment, because employment in Nigeria is a social class issue. Under privileged graduates who are then unemployed take to crime including violent conflict.The capitalist Nigerian economic structure with its unique feature of stall rationalization, exploitation of the labour force with its resultant effects of no industries to employ, and the closure of old industries incubate and hatch battalions of unemployed youths yearly. The retrenched youths from the closed industries who are re-employed to the unemployed market are usually potential and good recruits of the crime sector (Zunve, 2005). Writing on "youth crime in contemporary Nigeria, a social structure analysis", Zumve, (2005) opined that the current democratic dispensation has institutionalized and legitimized unethical democratic process. This creates youths in social criminal acts of thuggery. These militias are armed with weapons that later translated to means of arm robbery after they thugs are dumped by such politicians when elections are over. These thugs are most at times unemployed graduates.

\section{Methodology:}

The study employed Cross-sectional research design. The study uses both primary and secondary sources of data. The primary data were those collected from the field with the help of administration of questionnaires. Respondents were subjected to freedom of response relevant to the substantive issues of the study. The secondary sources of data collection include the use of textbooks, journals and other relevant materials related to the study.Simple random sampling method was employed for this study. One hundred and twenty (120) unemployed residents in Takum LGA were randomly sampled for the study. The study employed tables and simple percentages for the analysis of the data that were collected from the field. The raw data were sorted out, re-arranged and tabulated manually into frequency and percentages for easy interpretation. A simple percentage was used because it is the easiest statistical measure that can be used for descriptive purpose.

\section{Data Presentation And Analysis:}

This section captured information related to the research questions and the objectives of the study as presented below:

Table 1: Distribution Of Respondents' Opinion On Whether There Is High Level Of unemployment 
John Wajim/Youth Unemployment: The Cause of Ethnic Conflict and Criminal Activities in Takum Local Government Area of Taraba State Nigeria

among youths in Takum

LGA

of Taraba State, Nigeria

\begin{tabular}{|l|l|l|}
\hline Opinion & Frequency & Percentage \\
\hline Yes & 87 & 87.0 \\
\hline No & 13 & 13.0 \\
\hline Total & $\mathbf{1 0 0}$ & $\mathbf{1 0 0}$ \\
\hline
\end{tabular}

Source: Field Survey, (2016)

The data reveals that $87 \%$ of the respondents emphasized that jobs in Taraba State and Takum precisely are secured based on ethnic nepotism and connection. $13 \%$ out of $100 \%$ maintained that jobs in Takum particularly is base on who one knows and ethnic nepotism. The implication of this findings shows that since jobs in Takum LGA is based on ethnic nepotism and connection many youths who don't have people to help them secure employment are unemployed.

Table 2: Distribution Of Respondents' Opinion On Unemployment As The Cause Of Crime In Takum

LGA of Taraba State, Nigeria

\begin{tabular}{|l|l|l|}
\hline Response & Frequency & Percentage \\
\hline Yes & 89 & 89.0 \\
\hline No & 11 & 11.0 \\
\hline Total & $\mathbf{1 0 0}$ & $\mathbf{1 0 0}$ \\
\hline
\end{tabular}

\section{Source: Field Survey, (2016)}

Date in table 2 seeks to find out the relationship between youth unemployment and crime. The finding reveals that $89 \%$ respondents agreed with the views that unemployment causes crime in Takum LGA of Taraba State. On the contrary $11 \%$ of the respondents disagreed. The implication of this finding is that unemployment causes crime. This is hinge on the fact that young people are prone to device any means possible including criminal acts in order to survive and acquire materials success.

Table 3: Distribution Of Respondents' Opinion On Youth Unemployment As The Cause Of Ethnic Conflict In Takum

\section{LGA Of Taraba State, Nigeria}

\begin{tabular}{|l|l|l|}
\hline Response & Frequency & Percentage \\
\hline Yes & 89 & 89.0 \\
\hline No & 11 & 11.0 \\
\hline Total & $\mathbf{1 0 0}$ & $\mathbf{1 0 0}$ \\
\hline
\end{tabular}

Source: Field Survey, (2016)

The aforesaid question seeks to ascertain the relationship between youth unemployment and ethnic conflict in Takum LGA of Taraba State. The finding reveals that $89 \%$ of the respondents agreed with the views that unemployment causes ethnic conflict in the study area. On the contrary $11 \%$ of the respondents disagreed. The implication of the finding indicates that unemployment causes ethnic conflict in Takum LGA of Taraba State.This is center on the facts that young people are prone to sort for any means possible including ethnic conflict in order to acquire materials success and survive.

Table 4: Distribution Of Respondents' Opinion On The Effective Strategies To Tackle The Menace Of Youth Unemployment In Takum

LGA of Taraba State, Nigeria

\begin{tabular}{|l|l|l|}
\hline Opinion & Frequency & Percentage \\
\hline $\begin{array}{l}\text { Creation } \\
\text { industries }\end{array}$ & 89 & 49.0 \\
\hline Farming & 18 & 18.0 \\
\hline Infrastructure & 33 & 33.0 \\
\hline Total & $\mathbf{1 0 0}$ & $\mathbf{1 0 0}$ \\
\hline
\end{tabular}

Source: Field Survey, (2016)

The aforementioned data unveiled that $89 \%$ of the respondents in Takum LGA of Taraba State advocated for creation of more industries which will help the teaming unemployed youths to be employed in order to curtail idleness. $18 \%$ of the respondents responded that if youths can embark on farming the menace of unemployment will be curtailed. Finally $33 \%$ of the respondents opined that if there will be improvement in our infrastructure such as electricity most youths will engage into self employed businesses in order to curb the rate of criminal activities in the study area.It can be observed that the creation of more industries, engagement in agricultural activities and improvement of our power sector will serve as major panaceas to the reduction of unemployment among the youths in our society.

\section{Discussion Of Findings:}

From the findings, it was discovered that unemployment is prevalent among youths because employment in Takum LGA is secured based on nepotism and ethnic connection. This finding is in consonant with the view of Pittz, (2001) who maintained that unemployment as one of the prominent features of the Nigerian social structure has a causal relationship with youth criminality. He 
further stressed that the stratified nature of Nigerian society and its dominant social class features nepotism and ethnicity which plays a very important role on the issue of unemployment. Moreover, there are no industries in Taraba State and Takum LGA to be precise to absorb the unemployed youths. Beside this, numerous youths not only have preference for certain jobs but also lack skills to stimulate self employment.As regard to the relationship between unemployment and crime, it was evidently clear from the findings that unemployment causes criminal acts. This was justified by the fact that individuals (unemployed youths) are prone to device any possible means including crime to meet their material needs. The finding is tantamount to the opinion of Zumve, (2005) that says children of the majority are confronted with challenging experiences of inability to acquired good quality education and employment. Consequently, they take to crime in order to survive because of their social class. The finding also goes in line with the adopted theory of the study as postulated by Robert King Merton. Merton, (1938) unveiled that two social structures are involved in his strain theory; first is the culturally assigned goals and aspiration which are things that all individuals should want and expect out of life including both material and non material things. The second defined the acceptable means for achieving the goals and aspiration set by the society. For example, obeying laws and societal norms, seeking education and working hard. Merton argued that, there might not be a problem if everybody has equal access to these institutionalized means for achieving the sought after goals. However, if goals are not achieved through legitimate means, illegitimate means might be used to achieve the same goals, It was also tangible in table 3, on the tie between unemployment and ethnic conflict that the social ill (unemployment) instigates ethnic conflict by youths who are without jobs in order to have access by taking people's properties so as to survive and gain material wealth.Ibebuke, (2008) also asserted that unemployment is one of the major causes of incessant armed robbery in Nigeria, he succinctly opined that, a graduate who is unable to get a job and who out of frustration is psychologically bereft of any concept or idea of survival, such a person will definitely developed a negative attitude towards the social structure and will attribute his failure to the society's failure and the only way to manifest his integration is by constituting a terror to the well being of society.It was also discovered that, the need for material success among other factors are responsible for the involvement of unemployed youths in criminal activities and ethnic conflict. However, majority of the respondents emphasized on the need for material success as the principal cause of crime and ethnic conflict in the society. Chinqunta, (2002) sees unemployment as a visible idleness where youth congregate at bars and drinking places to converse or smoke marijuana for substantial part of the day. The above conceptualization of unemployment by Chinqunta clearly explained the fact that youths who are without employment can engage in any kind of anti social activities including ethnic conflict and criminal activities irrespective of the harm(s) that such acts may cause in the society provided that their goals can be met. This is tantamount to what Zimbabwe Ex-President Robert Mugabe said in one of his numerous quotes that, "How do you convince the upcoming generation that education is the key to success when we are surrounded by poor graduates and rich criminals?"Finally, the findings revealed that in order to curtail unemployment, more industries should be created. Moreover, there should be improvement in our agricultural and infrastructural sectors such as electricity which will stimulate self-employment.

\section{Conclusion:}

Based on the foregoing analysis, it is crystal clear that crime and unemployment among youths in Takum LGA of Taraba State has resulted to so many social vices and by no exception ethnic conflict and crime remain the standing consequences. The major concern of this research work is that if development is to be attained, these menacing phenomena must be adequately addressed. This is because the possible consequences of unemployment among youths (i.e ethnic conflict and criminal activities) can negatively impact on the socio-economic development of the study area in particular and the society at large.

\section{Recommendations}

It is recommended that;

i. There should be improvement in the infrastructural sector such as electricity in order to stimulate entrepreneurial development and curtail reliance on government for jobs. 
John Wajim/Youth Unemployment: The Cause of Ethnic Conflict and Criminal Activities in Takum Local Government Area of Taraba State Nigeria

ii. More industries should be created to absorb the unemployed youths. This can be done by the Government, Corporate bodies, Nongovernmental Organizations (NGOs) and Spirited Individuals.

iii. There should be diversification of economy. Here, other sectors of the economy such as Agricultural sector should be accorded more attention by the government and individuals been the mainstay of Nigeria's economy; the sector really need a boost.

iv. Youths especially graduates should not only look up on wage employment as the only means of employment, but should also use their physical strength either in farming or other businesses in order to avoid being ready instrument(s) of crime and war.

v. There should be value reorientation among the youths. This requires dogged determination by the family in inculcating in their youths values necessary to change their perception and possible reaction to their strain in quest for material success.

vi. The principle of meritocracy should be observed in employment process by our government departments, ministries and agencies. It has been observed that employment in Taraba state and Takum LGA to be precise is mostly based on nepotism and connection due to the structure of the society. This trend should be reversed in order to give equal opportunities for all irrespective one of ethnic and religion pedigree.

\section{References:}

1. Adelodun, S. (2005). How to be Your Own Boss. Jobletter Oragnization.

2. Bayo, A. (2005). "Rising Rate of Unemployment and Development of Nigeria" International Journals of Social and Policy Issues, 3(2): 166-123.

3. Bello, T. (2003). Attacking Unemployment Hurdles in the fragile Economics of the subSahara African. The experience Nigeria. Cambridge United Kindom.

4. Bolaji, A. (2009). Nigeria Government Must Tackle
Unemployment.http.www.tradingeconomics.co $\mathrm{m} /$ Nigeria.

5. Bolaji, A. (2009). Nigerian Government Must Tackle Unemployment. On http.www.tradingeconomics.com/ Nigeria. Bureau of statistics annual report (2007).

6. Bereau of Statistics Annual Report, (2007).

7. Graid, C. Donald, L. and Suzzane, N. (2005). Understanding Sociology. $\left(6^{\text {th }}\right.$ ed.)

8. McGraw Hill.

9. Carrabine, Eomoan, et al., (2004). Criminology; A sociological Introduction.

10. London: Rutledge.

11. Oxford English Dictionary, (2009). Second Edition on CD-ROM. Oxford:

12. Oxford University Press.

13. Damachi, N.A. (2001). Evaluation of the Past Policy Measures for Solving

14. Unemployment Problem in Nigeria. CBN Bulleting, 3(4).

15. Douglason, G.O. (2008). Youth Unemployment and Crime.

16. http.www.sunnewsonline.com/webnews.

17. Dinnah, J.C. (2008). Socio-economic implications of graduate Unemployment in Nigeria. A $\quad$ Term http//:www.sounnewsonline.com/webnews.

18. Eason, M. (17 June 2010). "What is Crime?"

19. (http:/www.bbc.co.uk/blogs/)thereporters/m arkeaston/2010/06/what is crime.html). BBC News. Retrieved 10 June2013.

20. Elizabeth, A.M. (2003). Oxford Dictionary of law ( $7^{\text {th }}$ ed.): oxford University Press.

21. Oxford Dictionaries, (2013). Oxford University press.

22. Retrieved 28 December 2013

23. Gidden, A. (2001). Sociology. Hong Kong, Mcgraw Hills.

24. Global employment trends, (2013). International labour Organization.

25. 21 January 2013

26. Graig C, Donald, L. \& Suzzane N. (2005). Understanding sociology. $6^{\text {th }}$ ed. McGraw Hills.

27. Haralarmbos, M., Holborn, M. (2004). 
John Wajim/Youth Unemployment: The Cause of Ethnic Conflict and Criminal Activities in Takum Local Government Area of

Sociology; themes and perspectives. $\left(6^{\text {th }} \mathrm{Ed}\right)$

Taraba State Nigeria

London, Harper Collins Limted.

28. Ibebuike, D. (2008). The menace of Arm robbery.

http:/www.sunnewsoline.com/webnew/opion/2008/ i/am/23/opion/23.01.2208.

29. International Labour Organization. (1982).

Resolution Concerning Statistics of the Economically Active Population, Employment, and Underemployment. Adopted by the Thirteenth international Conference of Labor Statisticians: see page 4". Retrieved 26 November 2007.

30. Ityavyar, D. A. (2000). The contribution of Nigeria youths to Nation building. A paper presented at the Nasarawa State Youth Festival.

31. Michael N. (1992). Rationality and the Analysis of International Conflict. Cambridge University Press. pp. 12-13. Retrieved 11 October 2012.

32. Okafor E.E (2011). Youth Unemployment and implication for stability of Democracy in Nigeria. ISDA, 13(1).

33. Otite O. and Albert O. I. (2007). Community Conflicts in Nigeria. Ibadan, Spectrum books limited.

34. Oviawe, J.O (2010). Repositioning Nigerian Youth for Economic Empowerment through Entrepreneurship Education. European Journal of Education Studies, 2(2): 113-118.

35. Rakhim, M. A. (2010). Managing Conflict in Organization. Transaction Publishers. pp. 15. Retrieved 11 October 2012.

36. Raphael N. E. (2005). Characteristics and Determinant of Urban Youth Unemployment in Umuahia: Implication for Rural Development and Alternative Labour Market Variables. http:/www.articlebase.com
37. Robert A. B. (1990). Conflict in Organizations. Psychology press. pp. 197-216. Retrived 11 October 2012.

38. The Saylor Foundation. "Unemployment Rate." Pp. 1 [1] Retrieved 20 June 2012

39. Why Money Matters. Retrieved 20 August 2013.

40. Wikipedia, the free encyclopedia "Criminal", "Criminally", and "Offender" redirect here. For other uses, see Crime (disambiguation), Criminal (disambiguation), and Offensive (disambiguation)

41. Zunve, S.I. (2005). Youth Crime in Contemporary Nigeria: a Social Structural Analysis. Makurdi. 